\title{
Structure and Physiology of the RET Receptor Tyrosine Kinase
}

\author{
Carlos F. Ibáñez \\ Department of Neuroscience, Karolinska Institute, S-17177 Stockholm, Sweden; Life Sciences Institute, \\ Department of Physiology, National University of Singapore 117456, Singapore \\ Correspondence: carlos.ibanez@ki.se
}

The identification of the ret oncogene by Masahide Takahashi and Geoffrey Cooper in 1985 was both serendipitous and paradigmatic (Takahashi et al. 1985). By transfecting total DNA from a human lymphoma into mouse NIH3T3 cells, they obtained one clone, which in secondary transformants yielded more than 100-fold improvement in transformation efficiency. Subsequent investigations revealed that the ret oncogene was not present as such in the primary lymphoma, but was derived by DNA rearrangement during transfection from normal human sequences of the ret locus. At the time, activation by DNA rearrangement had not been previously described for a transforming gene with the NIH3T3 transfection assay. The discovery of ret opened a field of study that has had a profound impact in cancer research, developmental biology, and neuroscience, and that continues to yield surprises and important insights to this day.

\section{AN UNUSUAL RECEPTOR TYROSINE KINASE WITH CADHERIN REPEATS}

solation of ret cDNA clones revealed a carboxy-terminal domain with high homology with members of the tyrosine kinase gene family preceded by a hydrophobic sequence characteristic of a transmembrane domain, suggesting that the ret oncogene encoded a cell-surface receptor (Takahashi and Cooper 1987). The characterization of the human (Takahashi et al. 1988) and mouse (Iwamoto et al. 1993; Pachnis et al. 1993) ret proto-oncogenes revealed the full primary structure of the RET protein and the unusual presence in its extracellular region of a sequence with similarity to cadherins, transmembrane proteins that mediate $\mathrm{Ca}^{2+}$-dependent homophilic cell adhesion (Nollet et al.
2000). A molecular modeling study of the extracellular domain of RET later revealed four cadherin repeats-termed cadherin-like domains or CLDs 1-4-each of about 110 residues, and one $\mathrm{Ca}^{2+}$-binding site between CLD2 and CLD3 (Anders et al. 2001). $\mathrm{Ca}^{2+}$ binding is required for the functional integrity of the RET protein and for its ability to interact with ligand. Following the four CLDs, the extracellular domain of RET contains a Cys-rich region of 120 residues connected to the transmembrane domain. The intracellular region of RET begins with a juxtamembrane portion of 50 residues, a tyrosine kinase domain split by a 14-residue linker, and a 100-residue-long carboxy-terminal tail, which comes in two flavors as a result of alternative splicing. After position 1063, the "short" RET isoform contains nine unique

Editors: Joseph Schlessinger and Mark A. Lemmon

Additional Perspectives on Receptor Tyrosine Kinases available at www.cshperspectives.org

Copyright (C) 2013 Cold Spring Harbor Laboratory Press; all rights reserved; doi: 10.1101/cshperspect.a009134

Cite this article as Cold Spring Harb Perspect Biol 2013;5:a009134 
carboxy-terminal residues (RET9), whereas the "long” contains 51 (RET51).

\section{ONE GENE, MANY DISEASES}

Mutations in the RET gene have been found in a number of human diseases, including several different cancers of neuroendocrine origin and a gut syndrome characterized by intestinal obstruction known as Hirschsprung's disease. Four different human cancers carry mutations in the RET gene, including papillary thyroid carcinoma (PTC) (Grieco et al. 1990), medullary thyroid carcinoma (familial and sporadic) (Donis-Keller et al. 1993; Hofstra et al. 1994), and the multiple endocrine neoplasias type $2 \mathrm{~A}$ (MEN2A) (Donis-Keller et al. 1993; Mulligan et al. 1993) and 2B (MEN2B) (Hofstra et al. 1994). Dozens of different substitutions and rearrangements in the RET gene underlie these syndromes, a complexity that has profound implications for our understating of genotype/ phenotype relationships and the molecular mechanisms of signal transduction (for an indepth review of the cancer biology of RET, see the article by Santoro and Carlomagno 2013). Although RETmutations that lead to tumor formation have in most cases been described as gain of function, mutations that result in Hirschsprung's disease-of which more than 50 are known so far-invariably result in loss of RET function by targeting its kinase activity (Iwashita et al. 1996; Pelet et al. 1998), docking sites for intracellular signaling effectors (Geneste et al. 1999), or residues in the RET extracellular domain that affect RET processing in the endoplasmic reticulum and prevent RET expression at the cell surface (Iwashita et al. 1996; Cosma et al. 1998; Kjaer and Ibanez 2003b).

\section{A WEALTH OF RET LIGANDS AND CORECEPTORS}

The RET ligand has been identified as glial cell line-derived neurotrophic factor (GDNF) (Durbec et al. 1996; Trupp et al. 1996), a dimeric growth factor-like protein distantly related to members of the transforming growth factor- $\beta$ (TGF- $\beta$ ) superfamily. Three additional proteins highly related in sequence to GDNF, known respectively as Neurturin (Kotzbauer et al. 1996), Persephin (Milbrandt et al. 1998), and Artemin (Baloh et al. 1998b), were subsequently also identified as ligands of RET. However, this ligand-receptor relationship proved to be a little more unusual than initially expected. Neither ligand is able to bind RETon its own, but require a ligand-binding subunit acting as coreceptor, known as the GDNF family receptor $\alpha(\mathrm{GFR} \alpha)$ component. Four different GFR $\alpha$ s have been described (GFR $\alpha 1-4)$, each with selectivityalthough not absolute specificity-for each of the four distinct members of the GDNF ligand family (Jing et al. 1996; Baloh et al. 1997, 1998a; Buj-Bello et al. 1997; Klein et al. 1997; Sanicola et al. 1997; Naveilhan et al. 1998; Trupp et al. 1998; Worby et al. 1998; Masure et al. 2000). GDNF can be chemically cross-linked to RET (Trupp et al. 1996), indicating that it does make direct contact with the receptor, although its binding affinity is too low to stabilize a complex. On the other hand, GDNF has high affinity for GFR $\alpha 1$ independently of RET. A model initially proposed had GDNF forming first a complex with GFR $\alpha 1$ and subsequently recruiting RET to the complex (Massague 1996). An alternative model, in which GFR $\alpha 1$ and RETare preassociated to some extent before ligand binding, was later proposed based on binding and sitedirected mutagenesis studies (Eketjäll et al. 1999; Cik et al. 2000). It should be noted that two additional receptors for GDNF have also been described, namely, the neural cell adhesion molecule NCAM (Paratcha et al. 2003) and syndecan-3 (Bespalov et al. 2011), which are able to transmit GDNF signals independently of RET.

\section{EVOLUTIONARY RELATIONSHIPS}

Only one ret gene is known to exist in higher organisms. RET, GDNF family ligands, and GFR $\alpha$ proteins have been found in all vertebrate species investigated so far. A ret orthologue has also been found in the genome of the cephalochordate Amphioxus, along with sequences corresponding to one GDNF-like and one GFR $\alpha$ like encoded protein product. RET is also found in Drosophila melanogaster. Intriguingly, its ex- 
pression pattern in the fly is to some extent reminiscent of the one found in vertebrates (Hahn and Bishop 2001). However, no GDNF or GFR $\alpha$ proteins appear to be encoded in the fly genome. Drosophila RET is unable to interact with GDNF or GFR $\alpha 1$ of mammalian origin, nor is it capable of mediating cell adhesion (Abrescia et al. 2005). A chimeric approach was used to show that Drosophila RET contains an active tyrosine kinase that is competent to induce neuronal differentiation on activation in PC12 cells (Abrescia et al. 2005). The physiological function of RET in Drosophila remains unknown.

\section{STRUCTURE-FUNCTION STUDIES OF RET EXTRACELLULAR AND KINASE DOMAINS}

Loss-of-function mutations in RET cause abnormal development of the enteric nervous system, leading to Hirschsprung's disease. Hirschsprung mutations in the extracellular domain of RET ( $\mathrm{RET}^{\mathrm{ECD}}$ ) affect processing in the endoplasmic reticulum (ER) and prevent RETexpression at the cell surface. Most Hirschsprung mutations examined prevent the maturation of $\mathrm{RET}^{\mathrm{ECD}}$ in the ER, indicating defects in protein folding (Kjaer and Ibanez 2003b). Maturation of RET $^{\mathrm{ECD}}$ mutants can be rescued by allowing protein expression to proceed at $30^{\circ} \mathrm{C}$, a condition known to facilitate protein folding, regaining their ability to bind to the GDNF/GFR $\alpha 1$. Analysis of autonomous folding subunits in the $\mathrm{RET}^{\mathrm{ECD}}$ has indicated an intrinsic propensity to misfolding in the amino-terminal CLDs 1-3 (Kjaer and Ibanez 2003b), which also concentrate the majority of Hirschsprung mutations affecting the $\mathrm{RET}^{\mathrm{ECD}}$. A recent crystal structure of the two amino-terminal CLD1-2 domains of the $\mathrm{RET}^{\mathrm{ECD}}$ has revealed these two CLDs folded onto each other in a compact clam-shell arrangement distinct from that of classical cadherins (Kjaer et al. 2010). CLD1 structural elements and disulfide composition are unique to mammals, indicating an unexpected structural diversity within higher and lower vertebrate RET CLD regions. The same study identified two unpaired cysteines that predispose human RET to maturation impediments in the ER. The intrin- sic susceptibility to misfolding of mammalian $\mathrm{RET}^{\mathrm{ECD}}$ may be the result of a trade-off that helps to avoid an increased incidence of tumors, at the expense of a greater vulnerability to Hirschsprung's disease.

Sequence and functional divergences between the ectodomains of mammalian and amphibian RET molecules have been exploited to map binding determinants in the human $\mathrm{RET}^{\mathrm{ECD}}$ responsible for its interaction with the GDNF-GFR $\alpha 1$ complex through homologscanning mutagenesis. It was found that Xenopus $\mathrm{RET}^{\mathrm{ECD}}$ was unable to bind to GDNFGFR $\alpha 1$ complexes of mammalian origin. However, a chimeric molecule containing CLD1, 2 , and 3 from human $\mathrm{RET}^{\mathrm{ECD}}$, but neither domain alone, had similar binding activity than full-length human RET $^{\mathrm{ECD}}$ (Kjaer and Ibanez 2003a). This suggested the existence of an extended ligand-binding surface within the three amino-terminal cadherin-like domains of human $\mathrm{RET}^{\mathrm{ECD}}$. Subsequently, a study using chemical cross-linking of a reconstituted GDNF/ GFR $\alpha 1 /$ RET complex followed by matrix-assisted laser desorption/ionization (MALDI) mass spectrometry analysis, indicated that CLD4 and the carboxy-terminal cysteine-rich domain (CRD) of the $\mathrm{RET}^{\mathrm{ECD}}$ are in direct contact with GFR $\alpha 1$ in complex with GDNF (Amoresano et al. 2005). This study failed to identify any direct contacts between RET and GDNF, although, as mentioned earlier, those were known to exist from previous cross-linking experiments (Trupp et al. 1996). These discrepant sets of results could be reconciled if the role of the aminoterminal CLD1-3 in ligand binding was indirect, rather than in establishing physical contact with the GDNF/GFR $\alpha 1$ complex. In this scenario, CLD1-3 would be necessary for RET to adopt a conformation that is competent for binding and complex assembly but not directly involved in contacting the RET ligands (Amoresano et al. 2005). At the time of this writing, efforts to solve the three-dimensional structure of the tripartite GDNF/GFR $\alpha 1 /$ RET complex are still ongoing, but preliminary results would seem to offer support for this latter model.

The crystal structures of the nonphosphorylated (inactive) and phosphorylated (active) RET 
kinase have been determined and shown to adopt the same active kinase conformation competent to bind ATP and substrate (Knowles et al. 2006). Both structures show a preorganized activation loop conformation that is independent of phosphorylation status. In agreement with the structural data, enzyme kinetic data showed that autophosphorylation produces only a modest increase in activity (Knowles et al. 2006). Longer forms of the RET intracellular domain containing the juxtamembrane domain and carboxy-terminal tail showed similar kinetic behavior as the isolated kinase, indicating the absence of a cis-inhibitory mechanism within the RET intracellular domain (Knowles et al. 2006). Unlike the situation of most other receptor tyrosine kinases, these results suggest the existence of alternative inhibitory mechanisms, possibly in trans, for the autoregulation of RET kinase activity.

\section{RET SIGNALING MECHANISMS}

Dimerization of receptor tyrosine kinases is known to be required, although most likely not sufficient, for ligand-induced kinase transphosphorylation and activation. Several receptor tyrosine kinases are found as preformed homodimers at the plasma membrane independently of ligand binding. Using a transmembrane (TM) domain self-association assay, Kjaer et al. observed strong self-association of the RET-TM in a biological membrane (Kjaer et al. 2006). These investigators found that mutagenesis of specific residues in the RET-TM domain reduced receptor homodimerization and abolished the transforming activity of MEN2A RET, one of the strongest oncogenic variants of the RET protein, suggesting that self-association of RET TM domains contributes to the mechanism of activation of RET (Kjaer et al. 2006).

Like the majority of receptor tyrosine kinases studied, signaling pathways initiated by the RET receptor include the Ras/MAP kinase, PI3 kinase/AKT, and phospholipase C- $\gamma$ (PLC $\gamma$ ) pathways. On activation, RETundergoes autophosphorylation of intracellular tyrosine residues, which then serve as docking sites for downstream signaling effectors carrying Src ho- mology 2 (SH2) or phosphotyrosine-binding (PTB) domains. Previous studies have indicated that at least 14 of the 18 tyrosine residues present in the intracellular region of RET can become phosphorylated (Liu et al. 1996; Kawamoto et al. 2004; Knowles et al. 2006). Among those, $\mathrm{Tyr}^{900}$ and $\mathrm{Tyr}^{905}$ are present in the kinase activation loop and are known to contribute to full kinase activation (Knowles et al. 2006). Autophosphorylation of the key residue $\mathrm{Tyr}^{1062}$ is required for activation of Ras/MAP kinase and PI3 kinase/AKT (Besset et al. 2000; Hayashi et al. 2000; Segouffin-Cariou and Billaud 2000; Coulpier et al. 2002). This residue appears to be critical for RET function, and mice with a point mutation in $\mathrm{Tyr}^{1062}$ show a severe loss-of-function phenotype (Jijiwa et al. 2004; Wong et al. 2005; Jain et al. 2006a). Phosphorylation of $\mathrm{Tyr}^{1096}$, present only in the long RET51 isoform, also contributes to these pathways. On ligand stimulation, at least two distinct protein complexes assemble on phosphorylated $\mathrm{Tyr}^{1062}$ of RET via Shc, one leading to activation of the Ras/MAP kinase pathway through recruitment of Grb2 and Sos, and another to the PI3K/AKT pathway through recruitment of adaptors Grb2 and Gab2 followed by p85 ${ }^{\mathrm{PI} 3 \mathrm{~K}}$ and the SHP2 tyrosine phosphatase (Besset et al. 2000).

The adaptor protein FRS2 can also bind to phosphorylated $\mathrm{Tyr}^{1062}$ in the activated RET receptor (Kurokawa et al. 2001; Melillo et al. 2001). FRS2 competes with Shc for binding to $\mathrm{Tyr}^{1062}$, and it has been shown that Shc but not FRS2 is responsible for cell survival effects of RET in neuroblastoma cells (Lundgren et al. 2006). This differential signaling may be mediated from different compartments in the plasma membrane, as RET has been shown to interact with FRS2 in lipid rafts, but with Shc outside lipid rafts (Paratcha et al. 2001). A series of adaptor molecules from the p62dok family have also been shown to interact with the activated RET receptor. Dok-1, $-2,-4,-5$, and -6 all interact with phosphorylated $\mathrm{Tyr}^{1062}$ via their PTB domains (Grimm et al. 2001; Crowder et al. 2004; Kurotsuchi et al. 2010) and are thought to contribute to neuronal differentiation (Grimm et al. 2001; Crowder et al. 2004). 
The Grb2/Gab2 complex can also assemble directly onto phosphorylated $\mathrm{Tyr}^{1096}$, offering an alternative route to PI3K activation by GDNF. Regarding the remaining autophosphorylation sites, it has been found that phosphorylation of $\mathrm{Tyr}^{1015}$ leads to activation of PLC $\gamma$ (Borrello et al. 1996), and phospho-Tyr ${ }^{981}$ binds the Src cytoplasmic tyrosine kinase (Encinas et al. 2004). Recently, a yeast-two-hybrid screen led to the identification of the GTPase-activating protein (GAP) for Rap1, Rap1GAP, as a novel RET-binding protein (Jiao et al. 2011). Like Src, Rap1GAP was also found to require phosphorylation of Tyr $^{981}$ for RET binding and suppressed GDNF-induced activation of ERK and neurite outgrowth. A recent study has established a biochemical function and a physiological role for the phosphorylation of $\mathrm{Tyr}^{687}$ in the juxtamembrane region of the RET intracellular domain (Perrinjaquet et al. 2010). Using a phage display strategy, Perrinjaquet et al. found that the phosphotyrosine phosphatase SHP2 binds to phospho-Tyr ${ }^{687}$ on ligand-induced RET activation. SHP2 is recruited to activated RET in a cooperative fashion, such that both interaction with $\mathrm{Tyr}^{687}$ and association with components of the $\mathrm{Tyr}^{1062}$ signaling complex are required for stable recruitment of SHP2 to the receptor. SHP2 recruitment was found to contribute to the ability of RET to activate the PI3K/AKT pathway and promote survival and neurite outgrowth in primary neurons (Perrinjaquet et al. 2010).

In addition to tyrosine autophosphorylation, RET has been found to undergo serine phosphorylation at Ser ${ }^{696}$ by protein kinase A (PKA) (Fukuda et al. 2002). Mutation of Ser ${ }^{696}$ affected the ability of RET to activate the small GTPase Rac1 and stimulate formation of cell lamellipodia (Fukuda et al. 2002). Homozygous knock-in mice carrying this mutation lacked neuronal elements of the enteric nervous system in the distal colon, resulting from a migration defect of enteric neural crest cells (Asai et al. 2006), indicating a physiological role for PKAdependent modification of RET function. Interestingly, the signaling deficits of the Ser ${ }^{696}$ RET mutant could be alleviated-at least in vitro-by simultaneous mutation of the nearby residue Tyr $^{687}$ (Fukuda et al. 2002). In line with this, activation of PKA by forskolin was found to impair the recruitment of SHP2 to RET and negatively affected ligand-mediated neurite outgrowth (Perrinjaquet et al. 2010). Moreover, mutation of Ser ${ }^{696}$ enhanced SHP2 binding to the receptor and eliminated the effect of forskolin on ligand-induced neurite outgrowth. Together, these findings established $\mathrm{Tyr}^{687}$ as a critical platform for integration of RET and PKA signals.

Among the interactions not mediated by phosphorylation, the PDZ domain-containing Shank3 protein was found to interact with a PDZ-binding motif present in the RET9 but not in the RET51 isoform (Schuetz et al. 2004). Shank3 was shown to mediate sustained MAP kinase and PI3 kinase signaling, and the formation of branched tubular structures in three-dimensional cultures of epithelial cells.

\section{RET FUNCTION IN KIDNEY DEVELOPMENT}

Knockout studies have shown that RET inactivation results in renal agenesis or severe hypodysplasia, owing to failure of the ureteric bud to evaginate from the Wolffian duct and branch normally (Schuchardt et al. 1994, 1996). RET expression defines a population of ureteric bud tip cells that proliferate under GDNF stimulation from the metanephric mesenchyme. In the absence of RET, tip cells change fate and instead contribute to the ureteric bud trunk (Shakya et al. 2005). Studies in knock-in mice have provided evidence for differential and isoform-specific roles of RET phospho-Tyr docking sites in kidney development. One earlier study initially reported that mice expressing only RET9 were normal, whereas those expressing only RET51 showed kidney hypodysplasia (de Graaff et al. 2001). In contrast, a later study reported that mice monoisomorphic for either RET9 or RET51 were viable and showed normal kidneys, indicating redundant roles of RET isoforms in kidney development (Jain et al. 2006a). As discussed elsewhere, a possible reason for this discrepancy may lie in the use of chimeric mouse-human knock-in cDNAs in the first study. It has also been reported that wild-type 
human RET51 and RET9 are both able to promote branching morphogenesis to a similar extent, but mutation of $\mathrm{Tyr}^{1062}$ abrogates this activity only in RET9 and not in RET51, presumably because of redundancy through $\mathrm{Tyr}^{1096}$ (Jain et al. 2006a). In contrast, mutation of Tyr ${ }^{1015}$ produced clear defects in ureteric bud outgrowth in the context of either isoform, providing evidence for the importance of PLC $\gamma$ signaling downstream from RET in renal development. Despite the prominent role of RET signaling in kidney development, no human RET mutations have yet been uncovered in children suffering from renal tract malformations.

\section{RET FUNCTIONS IN NERVOUS SYSTEM DEVELOPMENT}

\section{Enteric Nervous System}

Hirschsprung's disease is a genetic disorder of neural crest development characterized by the absence of enteric parasympathetic neurons in the lower regions of the gut. In agreement with a role in neural crest development, RET is expressed in several neuronal subpopulations derived from this structure, including cells in the enteric, sensory, and sympathetic nervous systems (Pachnis et al. 1993). Mice that are homozygotes for a targeted mutation in the RET gene lack enteric neurons throughout the digestive tract (Schuchardt et al. 1994). A subpopulation of enteric neural crest was found to undergo apoptotic cell death specifically in the foregut of embryos lacking the RET receptor (Taraviras et al. 1999). Together with defects in kidney organogenesis, this leads to the death of RET null animals at birth. It has more recently been found that conditional ablation of RET, or the GFR $\alpha 1$ coreceptor, in postmigratory enteric neurons causes widespread neuronal death in the colon, leading to colonic aganglionosis that resembles Hirschsprung's disease (Uesaka et al. 2007, 2008).

\section{Motoneurons}

RET is expressed in all spinal cord motoneurons from the earliest stages of their development
(Pachnis et al. 1993; Trupp et al. 1997; Garcès et al. 2000). GDNF has potent survival activities in spinal motoneurons (Henderson et al. 1994) and is required for their in vivo survival during late embryogenesis (Oppenheim et al. 2000). At early stages of development, RET is required for the topographic projection of hind limb-innervating axons, functioning as an instructive guidance signal for motor axons (Kramer et al. 2006). In this case, RET was shown to cooperate with the EphA4 receptor tyrosine kinase to enforce the precision of this binary choice in motor axon guidance. More recent studies using conditional alleles have shown that the effect of RET on motoneuron survival during programmed cell death is restricted to the early neonatal development of the subpopulation of $\gamma$-motoneurons that innervates muscle spindles (Gould et al. 2008). RET signaling would thus appear to have multiple effects on motoneuron survival and connectivity.

\section{Ventral Midbrain Dopaminergic Neurons}

GDNF was identified on the basis of its survivalpromoting effects on ventral midbrain dopaminergic neurons, which are important in the pathogenesis of Parkinson's disease (Lin et al. 1993). RET is expressed at high levels in adult ventral midbrain dopaminergic neurons of the substantia nigra, and exogenous application of GDNF was shown to protect RET-expressing neurons in this structure from cell death induced by 6-hydroxydopamine, an animal model of Parkinson's disease (Trupp et al. 1996). The robust effects of GDNF/RET signaling on dopaminergic neuron survival in several lesion paradigms naturally raised expectations of an important physiological function for RET in dopaminergic neurons, where it is expressed from very early stages of development. In agreement with this, knock-in of a constitutive allele of RET resulted in increased numbers of dopaminergic neurons and profound elevation of brain dopamine concentration, suggesting that RET signaling can have a direct biological effect in the brain dopaminergic system (Mijatovic et al. 2007). Despite the successes of gain-offunction approaches, the results from loss-of- 
function studies have been less clear-cut with regard to the importance of RET activity in dopaminergic neurons. Conditional ablation of RET in dopaminergic neurons has failed to reveal a prominent role for RET signaling in dopaminergic neuron development or maintenance, at least during the average life span of the mouse (Jain et al. 2006b; Kramer et al. 2007). One of these two studies, however, examined aging mutant mice and found that RET ablation caused progressive, but moderate, adult-onset loss of dopaminergic neurons in the substantia nigra and reduced dopaminergic nerve terminals in striatum, reaching 38\% reduction by 2 years of age (Kramer et al. 2007). In contrast to those mild effects, another study induced adult deletion of a conditional allele of Gdnf and found widespread deficits in dopaminergic and noradrenergic neurons (Pascual et al. 2008). As discussed elsewhere (Ibanez 2008), the striking discrepancy between these studies could be explained by the presence of alternative receptors for GDNF in dopaminergic neurons, compensatory effects in developing RET-deficient neurons, or the possibility that RET functions as a "dependence receptor" in dopaminergic neurons. Dependence receptors make cells that express them dependent on their ligands, and evidence from transformed cell lines has been provided suggesting that RETmight indeed function in this way (Bordeaux et al. 2000). At the time of this writing, independent efforts are underway to replicate several of the above-mentioned studies and so it is likely that the controversy over the physiological role of RET signaling in dopaminergic neuron survival and maintenance will become clarified before long.

\section{CONCLUDING REMARKS}

Nearly three decades after its discovery, unique aspects of RET function and physiology continue to fascinate biologists and biochemists. Unlike other receptor tyrosine kinases, autophosphorylation has only a modest effect on kinase activity, and so the mechanism of activation of the RET kinase remains elusive. The possibility of autoinhibition in trans is tantalizing and would mechanistically set RET apart from the bulk of other receptor tyrosine kinases. Its ligand system, with the GFR $\alpha$ coreceptors, is also rather unique, and upcoming crystal structures of the full ternary complex promise to reveal the mechanism of complex formation, and perhaps explain how a distant TGF- $\beta$ superfamily member ended up binding a receptor tyrosine kinase. These insights may also find applications in drug discovery. Indeed, although its physiological significance in dopaminergic neurons remains unclear, the robust effects of RET gain-of-function on the survival and function of these neurons has encouraged efforts to identify agonists for treatment of Parkinson's disease (Aron and Klein 2011). Such compounds may circumvent the intrinsic problems of protein delivery of current GDNF-based approaches.

\section{ACKNOWLEDGMENTS}

The author apologizes to all of the colleagues whose work could not be cited owing to space constraints. Work at the author's laboratory is funded by research grants from the Swedish Research Council, Swedish Cancer Society, Swedish Foundation for Strategic Research, European Research Council, and the National Institutes of Health.

\section{REFERENCES}

* Reference is also in this collection.

Abrescia C, Sjöstrand D, Kjaer S, Ibanez CF. 2005. Drosophila RET contains an active tyrosine kinase and elicits neurotrophic activities in mammalian cells. FEBS Lett 579: 3789-3796.

Amoresano A, Incoronato M, Monti G, Pucci P, de Franciscis V, Cerchia L. 2005. Direct interactions among Ret, GDNF and GFR $\alpha 1$ molecules reveal new insights into the assembly of a functional three-protein complex. Cell Signal 17: 717-727.

Anders J, Kjar S, Ibanez CF. 2001. Molecular modeling of the extracellular domain of the RET receptor tyrosine kinase reveals multiple cadherin-like domains and a calciumbinding site. J Biol Chem 276: 35808-35817.

Aron L, Klein R. 2011. Repairing the parkinsonian brain with neurotrophic factors. Trends Neurosci 34: 88-100.

Asai N, Fukuda T, Wu Z, Enomoto A, Pachnis V, Takahashi M, Costantini F. 2006. Targeted mutation of serine 697 in the Ret tyrosine kinase causes migration defect of enteric neural crest cells. Development 133: $4507-$ 4516. 
C.F. Ibáñez

Baloh RH, Tansey MG, Golden JP, Creedon DJ, Heuckeroth RO, Keck CL, Zimonjic DB, Popescu NC, Johnson EM, Milbrandt J. 1997. TrnR2, a novel receptor that mediates neurturin and GDNF signaling through Ret. Neuron 18: 793-802.

Baloh RH, Gorodinsky A, Golden JP, Tansey MG, Keck CL, Popescu NC, Johnson EM, Milbrandt J. 1998a. GFR $\alpha 3$ is an orphan member of the GDNF/neurturin/persephin receptor family. Proc Natl Acad Sci 95: 5801-5806.

Baloh RH, Tansey MG, Lampe PA, Fahrner TJ, Enomoto H, Simburger KS, Leitner ML, Araki T, Johnson EM, Milbrandt J. 1998b. Artemin, a novel member of the GDNF ligand family, supports peripheral and central neurons and signals through the GFR $\alpha 3$-RET receptor complex. Neuron 21: 1291-1302.

Bespalov MM, Sidorova YA, Tumova S, Ahonen-Bishopp A, Magalhães AC, Kulesskiy E, Paveliev M, Rivera C, Rauvala H, Saarma M. 2011. Heparan sulfate proteoglycan syndecan-3 is a novel receptor for GDNF, neurturin and artemin. J Cell Biol 192: 153-169.

Besset V, Scott RP, Ibanez CF. 2000. Signaling complexes and protein-protein interactions involved in the activation of the Ras and phosphatidylinositol 3-kinase pathways by the c-Ret receptor tyrosine kinase. J Biol Chem 275: 39159-39166.

Bordeaux MC, Forcet C, Granger L, Corset V, Bidaud C, Billaud M, Bredesen DE, Edery P, Mehlen P. 2000. The RET proto-oncogene induces apoptosis: A novel mechanism for Hirschsprung disease. EMBO J 19: 4056-4063.

Borrello MG, Alberti L, Arighi E, Bongarzone I, Battistini C, Bardelli A, Pasini B, Piutti C, Rizzetti MG, Mondellini P, et al. 1996. The full oncogenic activity of Ret/ptc2 depends on tyrosine 539, a docking site for phospholipase Cy. Mol Cell Biol 16: 2151-2163.

Buj-Bello A, Adu J, Piñón LG, Horton A, Thompson JF Rosenthal A, Chinchetru M, Buchman VL, Davies AM. 1997. Neurturin responsiveness requires a GPI-linked receptor and the Ret receptor tyrosine kinase. Nature 387: $721-724$.

Cik M, Masure S, Lesage AS, Van der Linden I, Van Gompel P, Pangalos MN, Gordon RD, Leysen JE. 2000. Binding of GDNF and neurturin to human GDNF family receptor $\alpha 1$ and 2. Influence of cRET and cooperative interactions. J Biol Chem 275: 27505-27512.

Cosma MP, Cardone M, Carlomagno F, Colantuoni V. 1998. Mutations in the extracellular domain cause RET loss of function by a dominant negative mechanism. Mol Cell Biol 18: 3321-3329.

Coulpier M, Anders J, Ibanez CF. 2002. Coordinated activation of autophosphorylation sites in the RET receptor tyrosine kinase: Importance of tyrosine 1062 for GDNF mediated neuronal differentiation and survival. J Biol Chem 277: 1991-1999.

Crowder R, Enomoto H, Yang M, Johnson E, Milbrandt J. 2004. Dok-6, a novel p62 Dok family member, promotes Ret-mediated neurite outgrowth. J Biol Chem 279: 4207242081.

de Graaff E, Srinivas S, Kilkenny C, D’Agati V, Mankoo BS, Costantini FD, Pachnis V. 2001. Differential activities of the RET tyrosine kinase receptor isoforms during mammalian embryogenesis. Genes Dev 15: 2433-2444.
Donis-Keller H, Dou S, Chi D, Carlson KM, Toshima K, Lairmore TC, Howe JR, Moley JF, Goodfellow P, Wells SA. 1993. Mutations in the RET proto-oncogene are associated with MEN 2A and FMTC. Hum Mol Genet 2: $851-856$.

Durbec P, Marcos-Gutierrez CV, Kilkenny C, Grigoriou M, Wartiowaara K, Suvanto P, Smith D, Ponder B, Costantini FD, Saarma M, et al. 1996. GDNF signalling through the Ret receptor tyrosine kinase. Nature 381: 789-793.

Eketjäll S, Fainzilber M, Murray-Rust J, Ibanez CF. 1999. Distinct structural elements in GDNF mediate binding to GFR $\alpha 1$ and activation of the GFR $\alpha 1$-c-Ret receptor complex. EMBO J 18: 5901-5910.

Encinas M, Crowder RJ, Milbrandt J, Johnson EM. 2004. Tyrosine 981, a novel ret autophosphorylation site, binds c-Src to mediate neuronal survival. J Biol Chem 279: $18262-18269$.

Fukuda T, Kiuchi K, Takahashi M. 2002. Novel mechanism of regulation of Rac activity and lamellipodia formation by RET tyrosine kinase. J Biol Chem 277: 19114-19121.

Garcès A, Haase G, Airaksinen MS, Livet J, Filippi P, Delapeyrière O. 2000. GFR $\alpha 1$ is required for development of distinct subpopulations of motoneuron. J Neurosci 20: 4992-5000.

Geneste O, Bidaud C, De Vita G, Hofstra RM, TartareDeckert S, Buys CH, Lenoir GM, Santoro M, Billaud M. 1999. Two distinct mutations of the RET receptor causing Hirschsprung's disease impair the binding of signalling effectors to a multifunctional docking site. Hum Mol Genet 8: 1989-1999.

Gould TW, Yonemura S, Oppenheim RW, Ohmori S, Enomoto H. 2008. The neurotrophic effects of glial cell linederived neurotrophic factor on spinal motoneurons are restricted to fusimotor subtypes. J Neurosci 28: 21312146.

Grieco M, Santoro M, Berlingieri MT, Melillo RM, Donghi R, Bongarzone I, Pierotti MA, Porta Della G, Fusco A, Vecchio G. 1990. PTC is a novel rearranged form of the ret proto-oncogene and is frequently detected in vivo in human thyroid papillary carcinomas. Cell 60: $557-563$.

Grimm J, Sachs M, Britsch S, Di Cesare S, SchwarzRomond T, Alitalo K, Birchmeier W. 2001. Novel p62dok family members, dok-4 and dok-5, are substrates of the c-Ret receptor tyrosine kinase and mediate neuronal differentiation. J Cell Biol 154: 345-354.

Hahn M, Bishop J. 2001. Expression pattern of Drosophila ret suggests a common ancestral origin between the metamorphosis precursors in insect endoderm and the vertebrate enteric neurons. Proc Natl Acad Sci 98: 1053-1058.

Hayashi H, Ichihara M, Iwashita T, Murakami H, Shimono Y, Kawai K, Kurokawa K, Murakumo Y, Imai T, Funahashi H, et al. 2000. Characterization of intracellular signals via tyrosine 1062 in RET activated by glial cell line-derived neurotrophic factor. Oncogene 19: 4469-4475.

Henderson C, Phillips H, Pollock R, Davies A, Lemeulle C, Armanini M, Simpson L, Moffet B, Vandlen R, Koliatsos V, et al. 1994. Gdnf: A potent survival factor for motoneurons present in peripheral-nerve and muscle. Science 266: 1062-1064. 
Hofstra RM, Landsvater RM, Ceccherini I, Stulp RP, Stelwagen T, Luo Y, Pasini B, Höppener JW, van Amstel HK, Romeo G. 1994. A mutation in the RET proto-oncogene associated with multiple endocrine neoplasia type $2 \mathrm{~B}$ and sporadic medullary thyroid carcinoma. Nature 367 : $375-$ 376.

Ibanez CF. 2008. Catecholaminergic neuron survival: Getting hooked on GDNF. Nat Neurosci 11: 735-736.

Iwamoto T, Taniguchi M, Asai N, Ohkusu K, Nakashima I, Takahashi M. 1993. cDNA cloning of mouse ret protooncogene and its sequence similarity to the cadherin superfamily. Oncogene 8: 1087-1091.

Iwashita T, Murakami H, Asai N, Takahashi M. 1996. Mechanism of ret dysfunction by Hirschsprung mutations affecting its extracellular domain. Hum Mol Genet 5: 1577-1580.

Jain S, Encinas M, Johnson EM, Milbrandt J. 2006a. Critical and distinct roles for key RET tyrosine docking sites in renal development. Genes Dev 20:321-333.

Jain S, Golden JP, Wozniak D, Pehek E, Johnson EM, Milbrandt J. 2006b. RET is dispensable for maintenance of midbrain dopaminergic neurons in adult mice. J Neurosci 26: $11230-11238$.

Jiao L, Zhang Y, Hu C, Wang Y-G, Huang A, He C. 2011. Rap1GAP interacts with RET and suppresses GDNF-induced neurite outgrowth. Cell Res 21: 327-337.

Jijiwa M, Fukuda T, Kawai K, Nakamura A, Kurokawa K, Murakumo Y, Ichihara M, Takahashi M. 2004. A targeting mutation of tyrosine 1062 in Ret causes a marked decrease of enteric neurons and renal hypoplasia. Mol Cell Biol 24: 8026-8036.

Jing S, Wen D, Yu Y, Holst PL, Luo Y, Fang M, Tamir R, Antonio L, Hu Z, Cupples R, et al. 1996. GDNF-induced activation of the ret protein tyrosine kinase is mediated by GDNFR- $\alpha$, a novel receptor for GDNF. Cell 85: 1113-1124.

Kawamoto Y, Takeda K, Okuno Y, Yamakawa Y, Ito Y, Taguchi R, Kato M, Suzuki H, Takahashi M, Nakashima I. 2004. Identification of RET autophosphorylation sites by mass spectrometry. J Biol Chem 279: 14213-14224.

Kjaer S, Ibanez CF. 2003a. Identification of a surface for binding to the GDNF-GFR $\alpha 1$ complex in the first cadherin-like domain of RET. J Biol Chem 278: 4789847904.

Kjaer S, Ibanez CF. 2003b. Intrinsic susceptibility to misfolding of a hot-spot for Hirschsprung disease mutations in the ectodomain of RET. Hum Mol Genet 12: 21332144.

Kjaer S, Kurokawa K, Perrinjaquet M, Abrescia C, Ibanez CF. 2006. Self-association of the transmembrane domain of RET underlies oncogenic activation by MEN2A mutations. Oncogene 25: 7086-7095.

Kjaer S, Heilshorn S, Totty N, McDonald NQ. 2010. Mammal-restricted elements predispose human RET to folding impairment by HSCR mutations. Nat Struct Biol 17: $726-731$.

Klein RD, Sherman D, Ho WH, Stone D, Bennett GL, Moffat B, Vandlen R, Simmons L, Gu Q, Hongo JA, et al. 1997. A GPI-linked protein that interacts with Ret to form a candidate neurturin receptor. Nature 387: $717-721$.
Knowles PP, Murray-Rust J, Kjaer S, Scott RP, Heilshorn S, Santoro M, Ibanez CF, McDonald NQ. 2006. Structure and chemical inhibition of the RET tyrosine kinase domain. J Biol Chem 281: 33577-33587.

Kotzbauer PT, Lampe PA, Heuckeroth RO, Golden JP, Creedon DJ, Johnson EM, Milbrandt J. 1996. Neurturin, a relative of glial-cell-line-derived neurotrophic factor. Nature 384: 467-470.

Kramer ER, Knott L, Su F, Dessaud E, Krull CE, Helmbacher F, Klein R. 2006. Cooperation between GDNF/ Ret and ephrinA/EphA4 signals for motor-axon pathway selection in the limb. Neuron 50: 35-47.

Kramer, Aron L, Ramakers, Seitz, Zhuang, Beyer, Smidt, Klein. 2007. Absence of Ret signaling in mice causes progressive and late degeneration of the nigrostriatal system. PLoS Biol 5: e39.

Kurokawa K, Iwashita T, Murakami H, Hayashi H, Kawai K, Takahashi M. 2001. Identification of SNT/FRS2 docking site on RET receptor tyrosine kinase and its role for signal transduction. Oncogene 20: 1929-1938.

Kurotsuchi A, Murakumo Y, Jijiwa M, Kurokawa K, Itoh Y Kodama Y, Kato T, Enomoto A, Asai N, Terasaki H, et al 2010. Analysis of DOK-6 function in downstream signaling of RET in human neuroblastoma cells. Cancer Sci 101: $1147-1155$.

Lin LF, Doherty DH, Lile JD, Bektesh S, Collins F. 1993. GDNF: A glial cell line-derived neurotrophic factor for midbrain dopaminergic neurons. Science 260: $1130-$ 1132.

Liu X, Vega QC, Decker RA, Pandey A, Worby CA, Dixon JE. 1996. Oncogenic RET receptors display different autophosphorylation sites and substrate binding specificities. J Biol Chem 271: 5309-5312.

Lundgren TK, Scott RP, Smith M, Pawson T, Ernfors P. 2006 Engineering the recruitment of phosphotyrosine binding domain-containing adaptor proteins reveals distinct roles for RET receptor-mediated cell survival. $J$ Biol Chem 281: 29886-29896.

Massagué J. 1996. Neurotrophic factors. Crossing receptor boundaries. Nature 382: 29-30.

Masure S, Cik M, Hoefnagel E, Nosrat CA, Van der Linden I, Scott RP, Van Gompel P, Lesage AS, Verhasselt P, Ibanez CF, et al. 2000. Mammalian GFR $\alpha$-4, a divergent member of the GFR $\alpha$ family of coreceptors for glial cell line-derived neurotrophic factor family ligands, is a receptor for the neurotrophic factor persephin. J Biol Chem 275: 39427-39434.

Melillo RM, Santoro M, Ong SH, Billaud M, Fusco A, Hadari YR, Schlessinger J, Lax I. 2001. Docking protein FRS2 links the protein tyrosine kinase RET and its oncogenic forms with the mitogen-activated protein kinase signaling cascade. Mol Cell Biol 21: 4177-4187.

Mijatovic J, Airavaara M, Planken A, Auvinen P, Raasmaja A, Piepponen TP, Costantini FD, Ahtee L, Saarma M. 2007. Constitutive Ret activity in knock-in multiple endocrine neoplasia type B mice induces profound elevation of brain dopamine concentration via enhanced synthesis and increases the number of TH-positive cells in the substantia nigra. J Neurosci 27: 4799-4809.

Milbrandt J, de Sauvage FJ, Fahrner TJ, Baloh RH, Leitner ML, Tansey MG, Lampe PA, Heuckeroth RO, Kotzbauer PT, Simburger KS, et al. 1998. Persephin, a novel 
C.F. Ibáñez

neurotrophic factor related to GDNF and neurturin. Neuron 20: 245-253.

Mulligan LM, Kwok JB, Healey CS, Elsdon MJ, Eng C, Gardner E, Love DR, Mole SE, Moore JK, Papi L. 1993. Germ-line mutations of the RET proto-oncogene in multiple endocrine neoplasia type 2A. Nature 363: 458-460.

Naveilhan P, Baudet C, Mikaels A, Shen L, Westphal H, Ernfors P. 1998. Expression and regulation of GFR $\alpha 3$, a glial cell line-derived neurotrophic factor family receptor. Proc Natl Acad Sci 95: 1295-1300.

Nollet F, Kools P, van Roy F. 2000. Phylogenetic analysis of the cadherin superfamily allows identification of six major subfamilies besides several solitary members. $J \mathrm{Mol}$ Biol 299: 551-572.

Oppenheim RW, Houenou LJ, Parsadanian AS, Prevette D, Snider WD, Shen L. 2000. Glial cell line-derived neurotrophic factor and developing mammalian motoneurons: Regulation of programmed cell death among motoneuron subtypes. J Neurosci 20: 5001-5011.

Pachnis V, Mankoo B, Costantini FD. 1993. Expression of the c-ret proto-oncogene during mouse embryogenesis. Development 119: 1005-1017.

Paratcha G, Ledda F, Baars L, Coulpier M, Besset V, Anders J, Scott RP, Ibanez CF. 2001. Released GFR $\alpha 1$ potentiates downstream signaling, neuronal survival, and differentiation via a novel mechanism of recruitment of c-Ret to lipid rafts. Neuron 29: 171-184.

Paratcha G, Ledda F, Ibanez CF. 2003. The neural cell adhesion molecule NCAM is an alternative signaling receptor for GDNF family ligands. Cell 113: 867-879.

Pascual A, Hidalgo-Figueroa M, Piruat JI, Pintado CO, Gómez-Díaz R, López-Barneo J. 2008. Absolute requirement of GDNF for adult catecholaminergic neuron survival. Nat Neurosci 11: 755-761.

Pelet A, Geneste O, Edery P, Pasini A, Chappuis S, Atti T, Munnich A, Lenoir G, Lyonnet S, Billaud M. 1998. Various mechanisms cause RET-mediated signaling defects in Hirschsprung's disease. J Clin Invest 101: 1415-1423.

Perrinjaquet M, Vilar M, Ibanez CF. 2010. Protein-tyrosine phosphatase SHP2 contributes to GDNF neurotrophic activity through direct binding to phospho-Tyr687 in the RET receptor tyrosine kinase. J Biol Chem 285 31867-31875.

Sanicola M, Hession CA, Worley D, Carmillo P, Ehrenfels C, Walus L, Robinson S, Jaworski G, Wei H, Tizard R, et al. 1997. Glial cell line-derived neurotrophic factor-dependent RETactivation can be mediated by two different cellsurface accessory proteins. Proc Natl Acad Sci 94: $6238-6243$.

* Santoro M, Carlomagno F. 2013. Central role of RET in thyroid cancer. Cold Spring Harb Perspect Biol doi: 10.1101/cshperspect.a009233.

Schuchardt A, D’Agati V, Larsson-Blomberg L, Costantini FD, Pachnis V. 1994. Defects in the kidney and enteric nervous system of mice lacking the tyrosine kinase receptor Ret. Nature 367: 380-383.

Schuchardt A, D'Agati V, Pachnis V, Costantini F. 1996. Renal agenesis and hypodysplasia in ret-k- mutant mice result from defects in ureteric bud development. Development 122: 1919-1929.
Schuetz G, Rosário M, Grimm J, Boeckers TM, Gundelfinger ED, Birchmeier W. 2004. The neuronal scaffold protein Shank3 mediates signaling and biological function of the receptor tyrosine kinase Ret in epithelial cells. J Cell Biol 167: 945-952.

Segouffin-Cariou C, Billaud M. 2000. Transforming ability of MEN2A-RET requires activation of the phosphatidylinositol 3-kinase/AKT signaling pathway. J Biol Chem 275: $3568-3576$.

Shakya R, Watanabe T, Costantini FD. 2005. The role of GDNF/Ret signaling in ureteric bud cell fate and branching morphogenesis. Dev Cell 8: 65-74.

Takahashi M, Cooper GM. 1987. ret transforming gene encodes a fusion protein homologous to tyrosine kinases. Mol Cell Biol 7: 1378-1385.

Takahashi M, Ritz J, Cooper GM. 1985. Activation of a novel human transforming gene, ret, by DNA rearrangement. Cell 42: 581-588.

Takahashi M, Buma Y, Iwamoto T, Inaguma Y, Ikeda H, Hiai H. 1988. Cloning and expression of the ret protooncogene encoding a tyrosine kinase with two potential transmembrane domains. Oncogene 3: 571-578.

Taraviras S, Marcos-Gutierrez CV, Durbec P, Jani H, Grigoriou M, Sukumaran M, Wang LC, Hynes MA, Raisman G, Pachnis V. 1999. Signalling by the RET receptor tyrosine kinase and its role in the development of the mammalian enteric nervous system. Development 126: 2785-2797.

Trupp M, Arenas E, Fainzilber M, Nilsson AS, Sieber B-A, Grigoriou M, Kilkenny C, Salazar-Grueso E, Pachnis V, Arumae U, et al. 1996. Functional receptor for GDNF encoded by the c-ret proto-oncogene. Nature 381: $785-$ 789.

Trupp M, Belluardo N, Funakoshi H, Ibanez CF. 1997. Complementary and overlapping expression of glial cell linederived neurotrophic factor (GDNF), c-ret proto-oncogene, and GDNF receptor- $\alpha$ indicates multiple mechanisms of trophic actions in the adult rat CNS. J Neurosci 17: 3554-3567.

Trupp M, Raynoschek C, Belluardo N, Ibanez CF. 1998. Multiple GPI-anchored receptors control GDNF-dependent and independent activation of the c-Ret receptor tyrosine kinase. Mol Cell Neurosci 11: 47-63.

Uesaka T, Jain S, Yonemura S, Uchiyama Y, Milbrandt J, Enomoto H. 2007. Conditional ablation of GFR $\alpha 1$ in postmigratory enteric neurons triggers unconventional neuronal death in the colon and causes a Hirschsprung's disease phenotype. Development 134: 2171-2181.

Uesaka T, Nagashimada M, Yonemura S, Enomoto H. 2008. Diminished Ret expression compromises neuronal survival in the colon and causes intestinal aganglionosis in mice. J Clin Invest 118: 1890-1898.

Wong A, Bogni S, Kotka P, de Graaff E, D’Agati V, Costantini FD, Pachnis V. 2005. Phosphotyrosine 1062 is critical for the in vivo activity of the Ret9 receptor tyrosine kinase isoform. Mol Cell Biol 25: 9661-9673.

Worby CA, Vega QC, Chao HH, Seasholtz AF, Thompson RC, Dixon JE. 1998. Identification and characterization of GFR $\alpha-3$, a novel co-receptor belonging to the glial cell line-derived neurotrophic receptor family. $J$ Biol Chem 273: 3502-3508. 


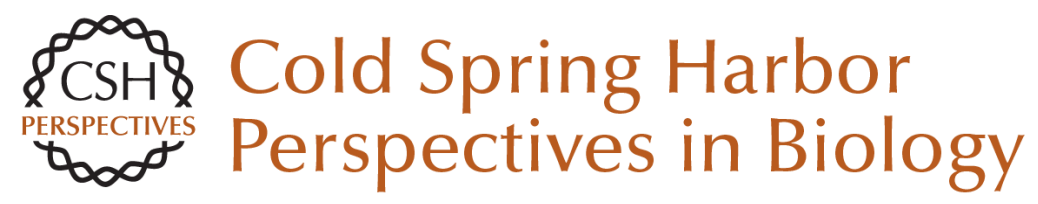

\section{Structure and Physiology of the RET Receptor Tyrosine Kinase}

Carlos F. Ibáñez

Cold Spring Harb Perspect Biol 2013; doi: 10.1101/cshperspect.a009134

Subject Collection Signaling by Receptor Tyrosine Kinases

CSF-1 Receptor Signaling in Myeloid Cells

E. Richard Stanley and Violeta Chitu

The EGFR Family: Not So Prototypical Receptor Tyrosine Kinases

Mark A. Lemmon, Joseph Schlessinger and Kathryn M. Ferguson

Tie2 and Eph Receptor Tyrosine Kinase Activation and Signaling

William A. Barton, Annamarie C. Dalton, Tom C.M. Seegar, et al.

The Spatiotemporal Organization of ErbB

Receptors: Insights from Microscopy

Christopher C. Valley, Keith A. Lidke and Diane S. Lidke

Insulin Receptor Signaling in Normal and Insulin-Resistant States

Jérémie Boucher, André Kleinridders and C. Ronald Kahn

Central Role of RET in Thyroid Cancer Massimo Santoro and Francesca Carlomagno

Receptor Tyrosine Kinase-Mediated Angiogenesis Michael Jeltsch, Veli-Matti Leppänen, Pipsa Saharinen, et al.

Biology of the TAM Receptors Greg Lemke
The Genesis of Tyrosine Phosphorylation Tony Hunter

Structure-Function Relationships of ErbB RTKs in the Plasma Membrane of Living Cells

Donna J. Arndt-Jovin, Michelle G. Botelho and Thomas M. Jovin

Receptor Tyrosine Kinases: Legacy of the First

Two Decades Joseph Schlessinger

The Role of Ryk and Ror Receptor Tyrosine Kinases in Wnt Signal Transduction Jennifer Green, Roel Nusse and Renée van Amerongen

Regulation of Receptor Tyrosine Kinase Ligand Processing Colin Adrain and Matthew Freeman

Molecular Mechanisms of SH2- and PTB-Domain-Containing Proteins in Receptor Tyrosine Kinase Signaling Melany J. Wagner, Melissa M. Stacey, Bernard A. Liu, et al.

Eph Receptor Signaling and Ephrins Erika M. Lisabeth, Giulia Falivelli and Elena B. Pasquale

Effects of Membrane Trafficking on Signaling by

Receptor Tyrosine Kinases Marta Miaczynska

For additional articles in this collection, see http://cshperspectives.cshlp.org/cgi/collection/

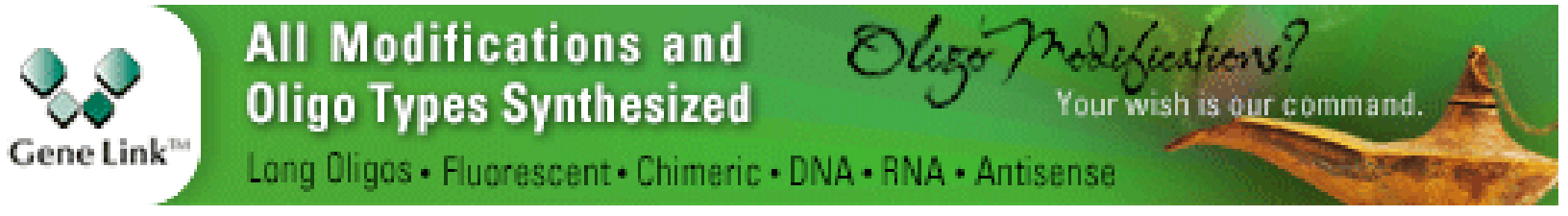


For additional articles in this collection, see http://cshperspectives.cshlp.org/cgi/collection/

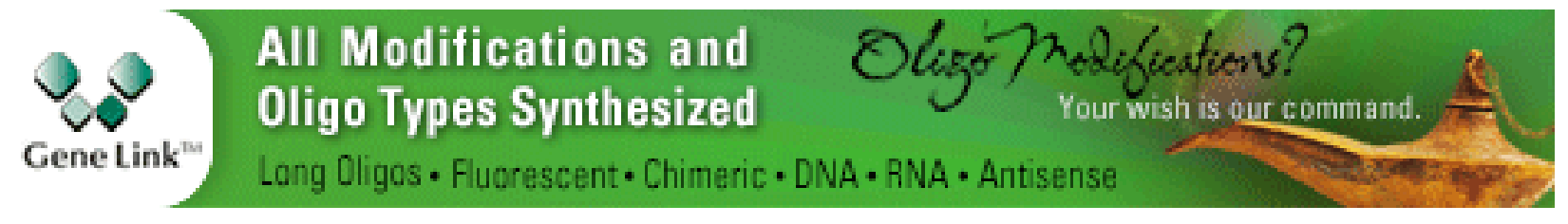

Copyright @ 2013 Cold Spring Harbor Laboratory Press; all rights reserved 